\title{
EFFECT OF DAYAK ONION TUBER (ELEUTHERINE AMERICANA MERR.) EXTRACT TO PREVENT INCREASED NECROSIS OF KIDNEY TUBULAR EPITHELIAL CELLS IN MICE (MUS MUSCULUS) TO ORAL LEAD ACETATE EXPOSURE
}

\author{
GADIS MEINAR SARI ${ }^{1 *}$, DAENG AGUS VIEYA PUTRI ${ }^{2}$, TJITRA WARDANI ${ }^{1}$, LILIK HERAWATI ${ }^{1}$
}

${ }^{1}$ Department of Physiology, Faculty of Medicine, Universitas Airlangga, Surabaya, Indonesia. ${ }^{2}$ Nusantara Institute of Health Science, Kupang, East-Nusa Tenggara, Indonesia. Email: gadis-m-s@fk.unair.ac.id

Received: 22 February 2019, Revised and Accepted: 25 July 2019

\section{ABSTRACT}

Objective: This study aims to determine the effect of Dayak onion tuber extract to prevent an increase in necrosis of kidney proximal tubular epithelial cells exposed to lead acetate.

Methods: Fresh Dayak onion tuber was extracted with $96 \%$ ethanol and then given orally to mice with doses of $65 \mathrm{mg} / \mathrm{kg}, 130 \mathrm{mg} / \mathrm{kg}$, and $260 \mathrm{mg} / \mathrm{kg}$ for 21 days, accompanied by 14 days of lead acetate on the $8^{\text {th }}-21^{\text {st }}$ days. Histological preparations of the mice's kidney were made by hematoxylin and eosin staining, and then, the necrosis of tubular cells was examined using a $\times 400$ magnification light microscope that observed 5 views randomly marked by the presence of pyknosis, karyorrhexis, and karyolysis.

Results: This study showed the higher the dose of Dayak onion tuber extract and the lower the number of tubular epithelial cell necrosis ( $<<0.05$ ).

Conclusion: Extract of Dayak onion tuber could prevent an increase in necrosis of kidney proximal tubular cells of mice that exposed to lead acetate.

Keywords: Dayak onion extract, Lead acetate, Necrosis, Tubular epithelial cells.

(C) 2019 The Authors. Published by Innovare Academic Sciences Pvt Ltd. This is an open access article under the CC BY license (http://creativecommons. org/licenses/by/4. 0/) DOI: http://dx.doi.org/10.22159/ijap.2019.v11s5.T1016

\section{INTRODUCTION}

The use of traditional medicines in Indonesia is essentially part of the Indonesian culture. The biodiversity of the Indonesian reaches to 30,000 species of plant and 940 of them are traditional medicinal plants. The advantage of using traditional medicine is it easily available in our surrounding, and empirically traditional medicine is able to cure various diseases, but its efficacy and capabilities have not been clinically proven yet [1].

Antioxidant compounds have an important role in the health of the human body. Various scientific evidence shows that antioxidant compounds can reduce various diseases because the main character of this compound is its ability to capture free radicals [2]. Free radicals are molecules that have too much or too few electrons to cause instability. Free radicals try to steal or give their electrons to other molecules so they can change their chemical structure [3]. Oxidative stress is a condition imbalance of the number of oxidants and pro-oxidants in the body which causes the activity of free radical molecules, or reactive oxygen species (ROS) attacks lipids, sugar, protein, and DNA so that it can cause cellular and genetic damage [4].

Lead is a toxic heavy metal used in the industrial world. Lead is found in everyday life, for example, in canned food, cosmetic ingredients, motor vehicle fuel, wall paint, plant fertilizers, and much more. The lead that enters the body through the digestive tract will accumulate in the blood and work to inhibit the $\delta$-aminolevulinic acid dehydratase (ALAD) enzyme, where this enzyme functions in hemoglobin synthesis [5]. In a series of chemosynthesis, because of this inhibition, there is an increase in the levels of ALA substrate which causes the formation of reactive bonds and produces ROS compounds [6]. The mechanism of ROS inflicts in cellular dysfunction and cell membrane lipid peroxidation which results in loss of calcium homeostasis from the mitochondria and endoplasmic reticulum. Then, because of the calcium levels are not well controlled, it can lead to cause tissues damage. Necrosis is irreversible damage that by the presence of degeneration, karyorrhexis, pyknosis, and karyolysis.

In this case, the kidney is the largest organ that receiving blood about $20-25 \%$ of cardiac output. Kidney damage can occur due to various diseases and commonly damaged the mass of the kidney. The proximal tubule is the most part that often damaged due to lead exposure. The predisposing factor that results in a perishable proximal tubule is the role that reabsorbs $60-80 \%$ of glomerular filtration. Other factors are the surface area of tubular re-absorption, the active transport system for ions and organic acids, and the ability of the tubules to concentrate the active transport system substances for ions, organic acids, low molecular proteins, peptides, and heavy metals that mostly occurring in the proximal tubules which cause its to damaged. Loose proximal tubular epithelium makes various components into tubular cells. This is also the cause of affecting tubular damage [7].

Indonesia's biodiversity is more than 30,000 species of plants and 940 of them are traditional medicinal plants. One of the traditional medicinal plants derived from onion Dayak (Eleutherine americana Merr.). There are many methods available in preventing costs due to exposure to free radicals, especially in this case lead which antioxidant content found in the Dayak onion tuber (E. americana Merr.). According to phytochemical analysis, it has a higher level of phenol and flavonoid. Previous research by Yuswa [8] proved that this plant has a total phenol content and high levels of flavonoids. The presence of antioxidants in the body is expected to compensate for free radical reactions that produced from various cells [9]. Phenol is a natural chemical compound that works as an antioxidant through a reducing mechanism, free radical capture, metal chelating to reduce the formation of reactive bonds, and electron donors. Flavonoids as antioxidants can protect cells from oxidative stress and reduce the risk of various degenerative diseases that associated with oxidative damage, and almost all flavonoids have strong antioxidant effects 
because they contain chemical elements responsible for antioxidant activity [10] quoted from Sandhar et al. [11].

Based on the description above, this study examined the effect of Dayak onion tuber extract (E. americana Merr.) to prevent an increase necrotic kidney tubular proximal epithelial cells of mice (Mus musculus) that exposed to peroral lead acetate, with the content framework as follows:

\section{METHODS}

Laboratory experimental research using the post-test, only control group design was applied. There were five groups consisting of the negative control and given a placebo orally for 21 days daily and positive control also given a placebo orally for 21 days and lead acetate by $50 \mathrm{mg} / \mathrm{kg}$ dose on $8^{\text {th }}-21^{\text {st }}$ days.

Group K1 was given Dayak onion tuber extract at a dose of $65 \mathrm{mg} / \mathrm{kg}$ for 21 days and lead acetate $50 \mathrm{mg} / \mathrm{kg}$ on $8^{\text {th }}-21^{\text {st }}$ days. Then, Group K2 was given Dayak onion tuber extract with a dose of $130 \mathrm{mg} / \mathrm{kg}$ for 21 days and lead acetate $50 \mathrm{mg} / \mathrm{kg}$ on $8^{\text {th }}-21^{\text {st }}$ days, and Group K3 was given Dayak onion tuber extract with a dose of $260 \mathrm{mg} / \mathrm{kg}$ for 21 days and lead acetate $50 \mathrm{mg} / \mathrm{kg}$ on $8^{\text {th }}-21^{\text {st }}$ days.
In addition, on the $22^{\text {nd }}$ day, all the mice were sacrificed to be dissected to taken their kidneys. Preparation in making kidney histology was using hematoxylin and eosin staining. Then, the necrosis of tubular cells was examined using a $\times 400$ magnification light microscope that observed 5 views randomly marked by the presence of pyknosis cells (the cell nucleus looks smaller, dense, and black), karyorrhexis (cell nucleus breaks into several clots), and karyolysis (nucleus cells pale, spread, or dissolve).

\section{RESULTS AND DISCUSSION}

Provision of Dayak onion tuber extract has been proven to prevent an increased kidney tubular epithelial cells in mice that exposed to oral lead acetate. Lead acetate is used as a trigger for the formation of free radicals so that ROS was formed, resulting in increased necrosis in proximal tubular epithelial cells.

Normal proximal tubular epithelial cell is seen in the negative control group (a) and necrotic proximal tubular epithelial cells (b), as shown in Fig. 1.

Based on the statistical test results, the data on the amount of necrotic epithelial cells in proximal tubules tested for normality with the Shapiro-Wilk test were obtained; all the data were normally distributed $(\mathrm{p}>0.05)$.

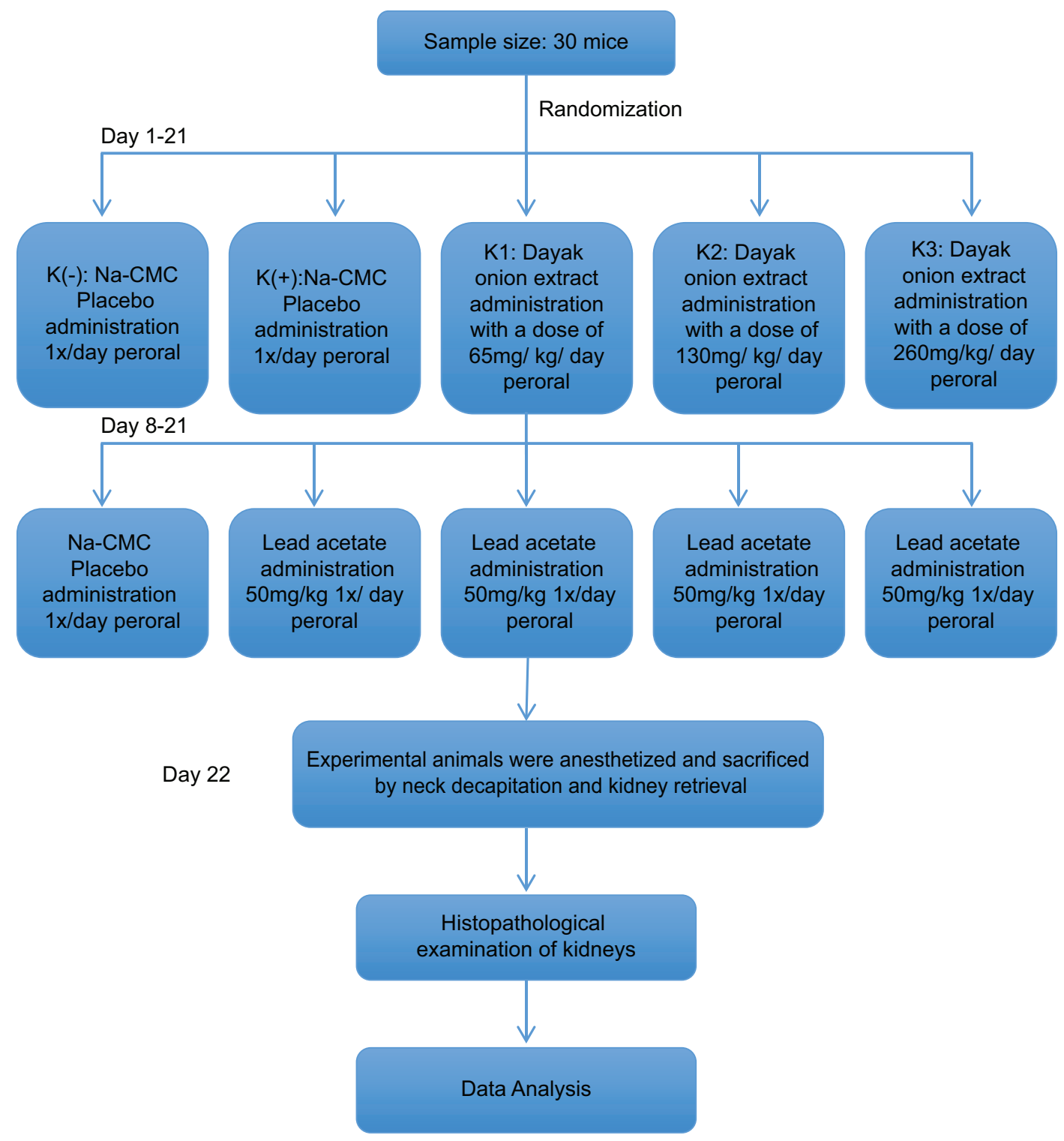




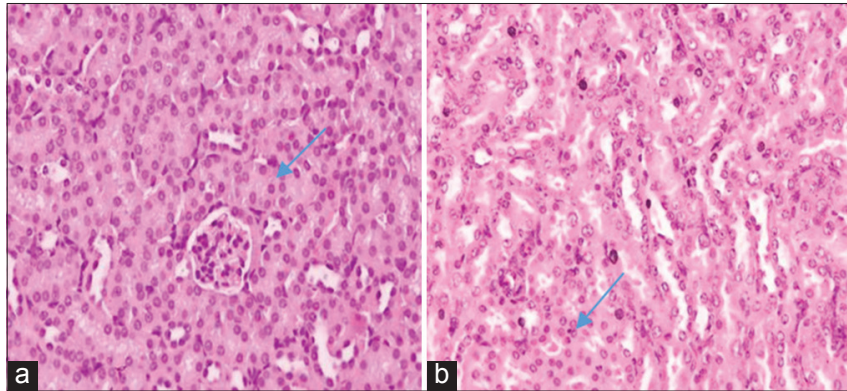

Fig. 1: (a) Normal proximal tubular epithelial cells, (b) necrotic proximal tubular epithelial cells, with hematoxylin and eosin staining $(\times 400)$

Table 1: Average of necrotic proximal tubular epithelial cells

\begin{tabular}{lll}
\hline Group & $\begin{array}{l}\text { Necrosis (\%) } \\
\text { (Mean } \pm \text { SD) }\end{array}$ & Brown-Forsythe sig. \\
\hline $\mathrm{K}(-)$ & $(2.967 \pm 1.856)$ & $0.001^{*}$ \\
$\mathrm{~K}(+)$ & $(14.833 \pm 3.829)$ & \\
$\mathrm{K}(1)$ & $(17.633 \pm 7.938)$ & \\
$\mathrm{K}(2)$ & $(6.167 \pm 1.717)$ & \\
$\mathrm{K}(3)$ & $(4.433 \pm 1.799)$ & \\
\hline
\end{tabular}

*Significant value $(\mathrm{p}<0.05)$. SD: Standard deviation

Based on the normality test above, then variance homogeneity of the data using Levene test has a result of $p<0.05$ means that the data were not homogeneous or have different variants $(p<0.002)$. Hence, the reading of the Brown-Forsythe test resulted in $\mathrm{p}<0.05$ which means statistically significant. This shows that the extract of Dayak onion tuber can prevent an increasing percentage of necrotic epithelial cells in proximal tubules in the treatment group significantly, as seen in Table 1.

This study used the extract of Dayak union tuber (E. americana Merr.) by giving in multilevel doses to each treatment groups (K1, K2, and K3). Group K1 was given a dose of $65 \mathrm{mg} / \mathrm{kg}$, the Group K2 was $130 \mathrm{mg} /$ $\mathrm{kg}$, and $\mathrm{K} 3$ was $230 \mathrm{mg} / \mathrm{kg}$. The percentage of necrotic epithelial cells in proximal tubules decreases by increasing the doses given of Dayak onion tuber extract. The content of phenol and flavonoids contained in the union work as an antidote to free radicals due to oxidative stress. The antioxidant activity in Dayak onion tuber extract was due to the content of total phenol and high flavonoid levels in 96\% ethanol. The higher the total phenol value, the higher the antioxidant activity produced. Antioxidant activity in flavonoid and phenol compounds with $-\mathrm{OH}$ groups which were bound to carbon aromatic rings [12].

The effect of lead hematotoxicity is to inhibit the conversion of the $\delta$-ALAD enzyme to porphobilinogen and the corporation from iron $(\mathrm{Fe})$ into the protoporphyrin IX to form hemoglobin. The inhibition of the $\delta$-ALAD enzyme resulted in the accumulation of $\delta$-ALA and protoporphyrin resulting in an inhibition of hemoglobin synthesis. In addition, lead inhibits the ferrochelatase enzyme, which causes iron ( $\mathrm{Fe}$ ) ions unable to bind to the protoporphyrin ring, and therefore, competition occurs between lead and Fe [13].

The physiological system of the body has the ability to reduce the damage of cells by peroxidation. However, if the body immune is weak or too much exposure to ROS, additional body protection mechanisms were needed. One form of additional protection was through the consumption of antioxidants which contained in many natural ingredients. All antioxidants can prevent lipid peroxidation [14].

Antioxidants are compounds that able to neutralize or stabilize free radicals by completing the lack of electrons in these free radicals. Antioxidants can prevent the occurrence of chain reactions from the formation of free radicals that can cause oxidative stress [15].
The mechanical action of antioxidants in free radicals has 3 ways, namely primary antioxidants, secondary antioxidants, and tertiary antioxidants. Here, the antioxidant content in Dayak onion tuber extract works on the mechanism of secondary antioxidants, namely Vitamin C, Vitamin E, Vitamin B, beta-carotene, and phytochemical compounds (flavonoids and carotenoids) that work by chelating metals as proxies, for example, lead, capturing radicals, and preventing fission reaction. Secondary antioxidants called as a chelating agent [16].

This study was a basic research on the effects of herbal extracts in improving organ function which was still at the treatment stage of experimental animals. Further research is still needed on the effectiveness of Dayak onion extracts and clinical trials in humans gradually. Considering that Dayak onion is easily available and affordable, thus it is expected to be able to be used as a natural alternative medicine to prevent increased necrosis in renal tubular epithelial cells due to lead acetate exposure.

\section{CONCLUSION}

Based on this study, it was proven that administration of Dayak onion tuber extract by doses of $65 \mathrm{mg} / \mathrm{kg}, 130 \mathrm{mg} / \mathrm{kg}$, and $260 \mathrm{mg} / \mathrm{kg}$ could prevent an increase in necrosis proximal tubular cells of mice that exposed to lead acetate. The percentage of necrotic epithelial cells in proximal tubules decreases by increasing the doses given of Dayak onion tuber extract.

\section{CONFLICTS OF INTEREST}

All authors have none to declare.

\section{REFERENCES}

1. Supriatna J. Melestarikan Alam Indonesia. Jakarta: Yayasan Obor Indonesia; 2016. p. 403.

2. Prakash A. Antioxidant activity. Medallion Lab Anal Prog 2001;19:1-4.

3. Michael TS. Perusahaan Ekstrak Metanol Daun Kesum (Polygonum minus Huds.) terhadap Peningkatan Kadar Kreatin dan Ureum Serum Tikus Putih Galur Wistar Terinduksi Sispalatin, Program Studi Farmasi Univeristas Tanjung Pura; 2013. p.6.

4. Harahap H. Pengaruh Pemberian Timbal Asetat secara Oral Tehradap Gambaran Histologik Epitel Jejejnum Tikus Putih (Rattus norvegicus) yang Diproteksi Vitamin E, Program Studi Ilmu Kedokteran Dasar, Jenjang Magister Fakultas Kedokteran. Universitas Airlangga; 2014

5. Palaar H. Pencemaran Dan Toksikologi Logam Berat. Jakarta: Rineka Cipta; 2008.

6. Komousani TA, Moselhy SS. Modulation of lead biohazards using a combination of epicatechin and lycopene in rats. Hum Exp Toxicol 2011;30:1674-81

7. Schnellman RG, Goldstein RS. Toxic responses of kidney. In: Klassen CD, editor. Casaret and Doull's Toxicology the Basic Science of Poisons. New York: The Mc Graw-Hill; 2001. p. 417-30.

8. Yuswi NC. Dayak onion antioxidant extraction with the ultrasonic bath method. Food J Agro Ind 2017;5:71-9.

9. Sel Epitel Tubulus Ginjal Tikus Al-Muqsith. Pengaruh Pemberian Xantone Terhadap Gambaran Putih yang Dinduksi Karbon Tetraklorida (CCL4) M.Si. Thesis, Program Studi Ilmu Kedokteran Dasar, Airlangga University; 2013.

10. Patel JM. A review of potential health benefits of flavonoids. Lethbridge Undergraduate Res J 2008:3:1-5.

11. Sandhar HK, Kumar B, Prasher S, Tiwari P, Salhan M, Sharman P. A review of phytochemistry and pharmacology of flavonoids. Int Pharm Sci 2011;1:25-41.

12. Pereira DM, Pereira JA, Andrade PB. Phenolics: From chemistry to biology. Molecules 2009;14:2202-11.

13. Siagian D. Dellta-aminolevulinic acid synthetase $(\Delta$-Alad) enzyme activity inhibition on heme biosynthesis due to plumbum exposure. VISI 2008;16:490-7.

14. Nugraha. Uji Antioksidan Umbi Bawang Lanang (Allium sativum) Terhadap Radikal Bebas DPPH (1,1-Difenil-2-Pikrihidrasi). Skripsi, Jurusan Farmasi, Stikes Bakti Husada; 2008.

15. Kikuzaki H, Natakani N. Antioxidants effects of some ginger constituent. J Food Sci 1993;58:1407-10.

16. Kartikawati D. Studi Efek Proktektif Vitamin C terhadap Respon Imun dan Enzim Antioksidan pada Mencit Yang Dipapar Paraquat. Thesis, Program Pasca Sarjana. Bogor: Institut Pertanian Bogor; 1999. 